\title{
Reproductive Biology of Neotropical Fishes: \\ A Guide to Identification to the Gonadal Morphology During the Reproductive Cycle of Catfish Rhamdia quelen (Siluriformes: Heptapteridae)
}

\begin{abstract}
Talita Sarah Mazzoni
Department of Cell and Developmental Biology, Institute of Biomedical Sciences, Federal University of Alfenas (UNIFAL), Gabriel Monteiro da Silva 700, 37130-001 Alfenas-MG, Brazil. Tel.: +55-35-3701-9568. E-mail: talitasarah@yahoo.com.br
\end{abstract}

Robie Allan Bombardelli

State University of West Paraná. Rua da Faculdade 645, 85903-300 Toledo-PR, Brazil. E-mail: rabombardelli@gmail.com

Irani Quagio-Grassiotto (Corresponding author)

Department of Morphology, Botucatu Biosciences Institute, State University of São Paulo (UNESP), Prof. Dr. Antonio Celso Wagner Zanin 250, 18618-689 Botucatu-SP, Brazil. Tel.: +55-14-3880-0468. E-mail: iraniqg@ibb.unesp.br

Received: May 30, 2020 Accepted: June 24, 2020 Published: June 29, 2020

doi:10.5296/ast.v8i2.17102 URL: https://doi.org/10.5296/ast.v8i2.17102

\begin{abstract}
In most Teleostei fish, the gametogenesis is a cyclical and seasonal event. The renewal of gametes, through their differentiation, development, maturation and release causes several changes in the morphological characteristics of the ovaries and testes throughout the annual reproductive cycles. These alterations are used to recognize different phases in the reproductive cycles. However, as the number of studies of fish reproduction increased, the number of types of gonadal classification and nomenclatures also diversified. This may make it difficult to communication between researchers and the aquaculture activity, since the recognition of these phases is one of the most important parameters applied in the management of fishery resources. In addition, the terminologies proposed in most of the
\end{abstract}


current studies refer to reproductive stages applicable to marine fish, with marked and defined seasonality characteristics. In this way, this report presents a recent proposal for the recognition of reproductive phases originally developed for the Perciformes and here adapted for the Neotropical Siluriformes, using as a biological model a freshwater catfish Rhamdia quelen. In addition, we describe a brief characterization of the gametogenesis in this species. We hope that the material presented can be used as an easy and practical guide of identification for reproductive phases applicable to other neotropical freshwater fish, more especially Otophysi, such as Siluriformes.

Keywords: reproductive phases, gametogenesis, gonads, freshwater fish, germinal epithelium, Ostariophysi

\section{Introduction}

Teleostei fish are the group with the highest number of species and the most diverse of all vertebrates. They dominate the world's rivers, lakes and oceans (Nelson, et al., 2016), presenting a great diversity of habitat. As a consequence, they constitute an extremely heterogeneous group in terms of anatomy, behavior and ecology (Nelson et al., 2016), in addition to presenting several reproductive strategies (Mann et al., 1984; Vazzoler, 1996). They are predominantly dioic and most of them have cyclical and seasonal reproduction, that is, both gonadal development and maturation of the gametes occur mainly at a certain time of the year, being frequently associated with a season (Vazzoler, 1996). Under favorable conditions, the gametes are released in a single or parceled form, and the reproduction of the species occurs. Thus, the gonadal development of the fish is cyclic and it accompanies the annual reproductive seasons. Throughout each reproductive cycle, the renewal of germ cells, their differentiation, development, maturation and release result in gonadal changes that characterize different reproductive phases, which is one of the parameters used in the management of fishing resources and reproductive handling of species (Lowerre-Barbieri et al., 2011 for review).

Among Teleostei, about $24 \%$ of species occupy neotropical freshwater (Vari and Malabarba, 1998), with the neotropical region being the richest in the number of freshwater fish species in the world (Albert and Reis, 2011). The neotropical ichthyofauna also represents the greatest diversity of species in the world, with approximately 9000 species (Malabarba and Malabarba, 2020).

The development of the neotropical fish gonads, as well as the other Teleostei, can be seen macroscopically, and changes in the shape, size, color and texture of the ovaries or testes have been used as parameters for the classification of the stage of maturation in which they are found. In studies on the reproductive biology of neotropical fish, the gonadal development of animals able for reproduction has been classified as: inactive, maturing, maturation or spawning, and spent or partially spent gonads, depending on the type of fecundity of the species considered (Vazzoler, 1996).

However, the histological analyses of these gonads has shown that the development of the germ cells is often discordant with the macroscopic classification of the gonad, since the 
stages of oocyte development and spermatogenesis determine the different reproductive phases, as well as the aspect of the gonad itself (Brown-Peterson et al., 2011 for review). In this regard, most studies on gonadal morphology and reproductive cycle in neotropical fish use standard terminology applied to non-tropical fish, often marine species, which have a very defined reproductive cycle, according to the seasons. The reflection of the climate changes on the gonadal phenotype throughout the seasons facilitates the classification of the gonads in specific reproductive phases. In neotropical fish, this classification is difficult due to the fact that the gonads do not present defined development patterns, as a consequence of poorly defined annual seasons in tropical countries. Thus, in species that occupy neotropical freshwater, the gametic cells are found in different stages of development, throughout the reproductive cycle. Therefore, defining them in a specific reproductive phase becomes a challenge.

In this context, in order to facilitate the understanding of the tools used in the studies of the reproductive biology of neotropical fish, we describe here the main events that occur in the gonads of Rhamdia quelen species, representing one of the main neotropical freshwater teleosts. $R$. quelen is an Ostariophysi belonging to the order Siluriformes, known as catfish (Bockmann, 1998). These representatives are quite hardy such and adaptable for artificial spawning and handling. They possess many characteristics necessary for aquaculture including relatively high fecundity, ability for artificial spawning, adaptability to earthen ponds for culture and high tolerance to biotic and abiotic factors (Jin et al., 2016). These characteristics make catfish one of the most popular groups of fish for aquaculture. Besides, Siluriformes is one of the largest orders of Teleostei; they are highly diverse and distributed worldwide containing approximately 4100 species, representing 12\% of all Teleostei (Jin et al., 2016; Nelson et al., 2016) and 37.1\% of the neotropical fish fauna (Malabarba and Malabarba, 2020). They are commonly found in inland or coastal waters of all continents, being most abundantly distributed in the tropics of South America, Africa and Asia (Jin et al., 2016).

In the same way, $R$. quelen has been widely recorded from the Brazilian Atlantic Coastal rivers, being considered a species complex (Angrizani and Malabarba, 2018).

Thus, due to the worldwide distribution and diversity of the catfish, $R$. quelen is interesting biological model to studies about reproductive cycle of neotropical catfishes. When addressing the dynamics of the organization and development of the germ cells of $R$. quelen, as well as the main parameters used in the classification of gonadal structure and germinal epithelium in both sexes, we hope to provide a simplified study guide that facilitates the identification of different cell types, structures gonadal and reproductive phases applicable to neotropical freshwater species, more especially, Otophysi. The correspondences of the names of the reproductive phases for the previously used names and their histological characterization were also adapted here so that these phases can be applied to Otophysi. 


\section{Method}

\subsection{Animals}

The juveniles of Rhamdia quelen, obtained by artificial reproduction, were reared under natural temperature and photoperiod conditions, and were fed daily with commercial feed containing $32 \%$ crude protein, $9 \%$ crude fiber, $9 \%$ minerals, $6 \%$ lipids and $250 \mathrm{mg} / \mathrm{kg}$ vitamin C. The experiment was performed for 24 months (January 2012 - December 2013) and at least 4 females and 4 males were randomly sampled every month, in a total of 200 specimens. The sampling was initiated in animals with a year old. The fishes were anesthetized with $0.1 \%$ benzocaine and euthanized according to the institutional animal care protocols and approval (375/2011 - CEUA - IBB/UNESP). The dissected gonads were fixed by immersion in fixative solution for histological analyzes.

\subsection{Macroscopic Characterization and Sample Preparation for Light Microscopy}

After dissection of the gonads, the ovaries and testes of $R$. quelen were used for macroscopic characterization of the reproductive phases. For histology, the gonads of $R$. quelen were fixed by immersion in $2 \%$ glutaraldehyde and $4 \%$ paraformaldehyde in Sorensen's phosphate buffer (0.1 M, pH 7.2) for at least $24 \mathrm{~h}$. Samples were dehydrated in ethanol and embedded in Historesin (Leica HistoResin $\left.{ }^{\circledR}\right)$. Cross sections $(3 \mu \mathrm{m})$ were stained with Hematoxylin-Eosin. The material was evaluated for developmental stages of the germinal epithelium and characterization of reproductive phases, according to Brown-Peterson and collaborators (2011). The gonads and sections were documented using a photographic camera (Sony Cyber Shot Dsc-H10) and computerized image analyzer (Leica LAS Interactive Measurements), respectively. Schemes were drawn based on the observed histological characteristics, using an image editor (CorelDRAW Graphics-Suite-X5).

\section{The Origin of the Gametes in Teleost Fish}

In Teleostei, including Rhamdia quelen, the gametogenesis begins from oogonia (Figure 1) or spermatogonia (Figure 2) in the germinal epithelium of the ovarian lamellae in female or in the germinal epithelium of the seminiferous tubules (testicular tubules) in male, respectively (Grier, 2002). In both sexes, undifferentiated oogonia surrounded by the cytoplasmic projections of the pre-follicle cells (Quagio-Grassiotto et al., 2011) (Figure 1A-C, A'-C'), and undifferentiated spermatogonia surrounded by the cytoplasmic projections of the Sertoli cells (see Schulz et al., 2010 for review) (Figure 2 A-C, A'-C') have a discontinuous distribution in the germinal epithelium.

The self-renewal (by mitosis) of these undifferentiated germ cells ensures the continuous production of gametes in the females and males of teleost fish (Schulz et al., 2010; Quagio-Grassiotto et al., 2011, 2013). Oogonia and spermatogonia resulting from mitotic divisions are progressively enveloped by pre-follicle cells (Nakamura et al., 2010, 2011; Quagio-Grassiotto et al., 2011) and by Sertoli cells (Schulz et al., 2010), respectively, forming germline cysts (Figure 1 D-E, D'-E' and 2 C-D, C'-D'). Within the cysts of females and males, the now differentiated oogonia and the generations of undifferentiated and differentiated spermatogonia continue undergoing mitosis, forming a cluster of 
interconnected cells, called germline cyst in females (Pepling et al., 1999) and spermatocyst in males (see Grier and Uribe-Aranzábal, 2009 for review). After a certain number of mitotic cycles, still inside the cysts, the differentiated oogonia, as well as the latest generation of differentiated spermatogonia, enter meiosis, giving rise to the oocytes and spermatocytes, respectively, which remain interconnected by intercellular bridges (Schulz et al., 2010; Quagio-Grassiotto et al., 2011, 2013).

In females, the meiosis of the oocytes progresses (Figure 1 F-L, F'-D') and it is stationed in late diplotene, when intercellular bridges are broken by pre-follicle cells, with consequent individualization of the oocytes (Quagio-Grassiotto et al., 2011), giving rise to ovarian follicles (Mazzoni et al., 2010; Mazzoni and Quagio-Grassiotto, 2017). These cells, now called follicle cells, synthesize their own basement membrane (França et al., 2010; Mazzoni et al., 2010), In this way, the follicle cells remain attached for a certain extent to the basement membrane of the lamellar epithelium. Cells from the ovarian stroma surround the ovarian follicles forming the theca. The oocytes accumulate yolk globules, develop and mature inside the follicles, segregated from the ovarian stroma by the basement membrane (Grier et al., 2009; Nakamura et al., 2010; Quagio-Grassiotto et al., 2010; Mazzoni and Quagio-Grassiotto, 2017). Meiosis is resumed at the end of maturation and it is only completed with fertilization. Ovulation occurs near the shared region of the basement membrane between the ovarian follicle and the lamellar epithelium. The oocyte development in $R$. quelen is illustrated in the Figures 3, 4 and 5.

In $R$. quelen males, as in most teleost fish, the meiosis is completed within the spermatocysts (Figure 2). Then, the differentiation of gametes occurs, even inside these cysts (Grier and Uribe-Aranzábal, 2009; Schulz et al., 2010). In some species, spermatogenesis is semi-cystic. In this case, the cysts open at the end of meiosis and spermatocytes are released into the luminal compartment of the testis. Thus, the spermatogenesis is completed in testicular lumen (see Jamieson, 2009 for review). The opening of the cysts can also occur during spermiogenesis, and the final sperm differentiation is finished in the luminal compartment (Quagio-Grassiotto et al., 2012). In males, regardless of the type of spermatogenesis (cystic or semi-cystic), all gametes development occurs segregated from the interstitial compartment of the testes by the basement membrane (Grier and Uribe-Aranzábal, 2009; Schulz et al., 2010; Mazzoni et al., 2014). The spermatogenesis in R. quelen is illustrated in the Figure 2.

\section{Reproductive Phases}

The nomenclatures used for each reproductive period are still quite diverse, although there is a certain worldwide consensus considering the events that occur during the reproductive stages in fish. Thus, in an attempt to universalize these nomenclatures Brown-Peterson and collaborators (2011) presented a proposal for characterizing the Reproductive Phases of the teleosts, considering together macro and microscopic aspects of the gonads throughout the reproductive cycle. 


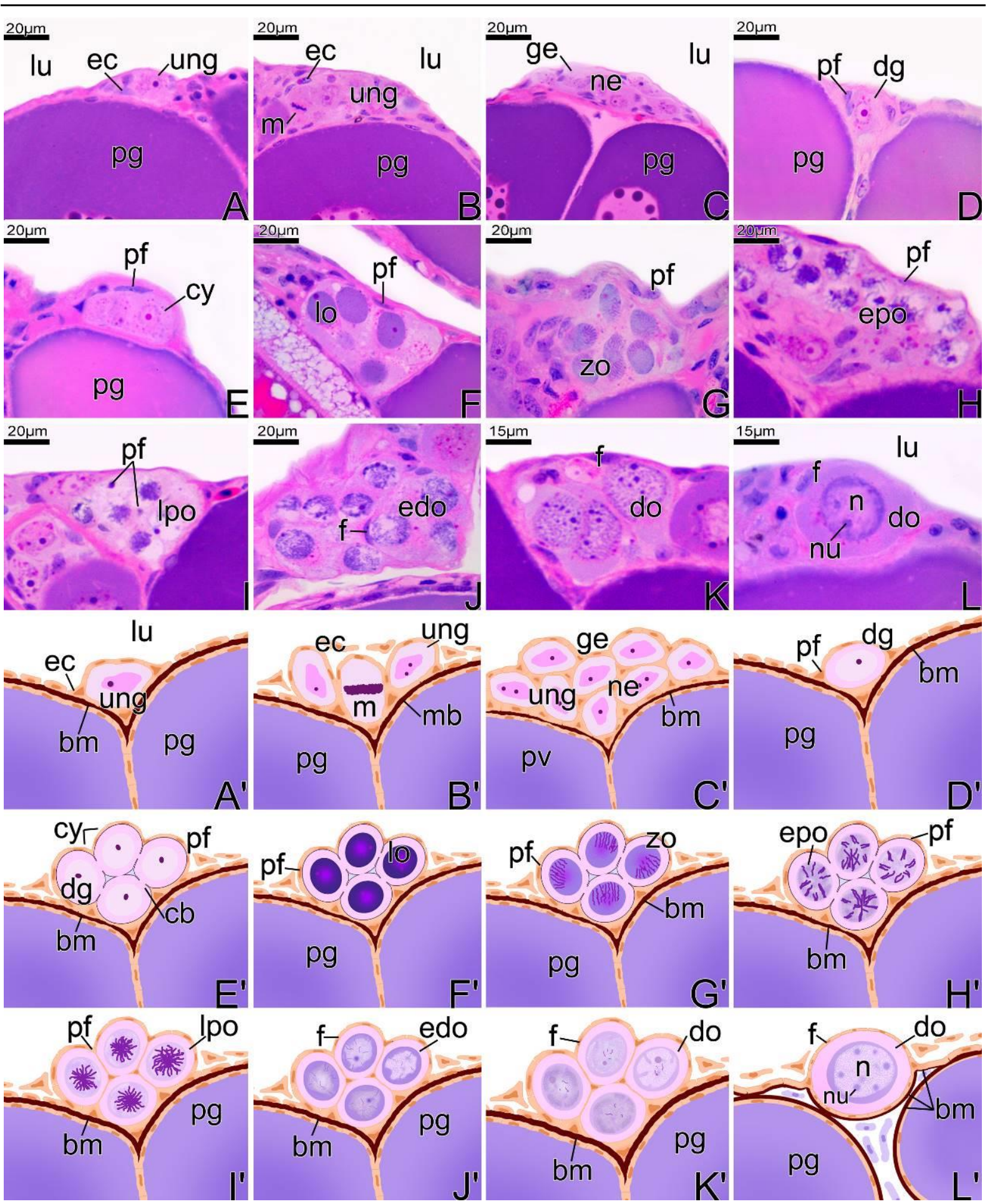

Figure 1. Folliculogenesis in Rhamdia quelen. A-L) Histological sections of the ovary, showing the cell nests region in the germinal epithelium. A'-L') Schemes of the steps of the Folliculogenesis presented in A-L. A and $\mathrm{A}^{\prime}$ ) Undifferentiated oogonium surrounded by epithelial cells. B and B') Proliferation of undifferentiated oogonium. C and $C^{\prime}$ ) Nest formation, consisting of numerous undifferentiated oogonia. D and D') Differentiated oogonia surrounded by pre-follicle cells, forming a germline cyst. E and E') Cyst of differentiated oogonia, delimited by pre-follicle cells. F and F') Cyst of leptotene oocyte. G and G') Cyst of zygotene oocyte. $\mathrm{H}$ and $\mathrm{H}^{\prime}$ ) Cyst of early pachytene oocyte. Note that the cyst is still 
delimited by pre-follicle cells. Staining: HE. I and I') Cyst of late pachytene oocyte being invaded by pre-follicle cells. $\mathbf{J}$ and $\mathrm{J}^{\prime}$ ) early diplotene oocytes already individualized by follicle cells. $\mathrm{K}$ and $\mathrm{K}^{\prime}$ ) Newly formed follicles, formed by diplotene oocytes and follicle cells. L and L') Diplotene oocyte leaves the cell nest to enter into primary growth. Note in A'-L' the presence of the basement membrane. The folliculogenesis process occurs above the basement membrane, in the germinal epithelium. Ovarian lumen (lu), epithelial cell (ec), undifferentiated oogonia (ung), primary growth oocyte (pg), metaphase (m), nest (ne), differentiated oogonia (dg), pre-follicle cell (pf), cyst (cy), leptotene oocyte (lo), zygotene oocyte (zo), early pachytene oocyte (epo), late pachytene oocyte (lpo), early diplotene oocyte (edo), follicle cell (f), diplotene oocyte (do), nucleus (n), nucleolus (nu), basement membrane (bm), cytoplasmic bridge (cb). Staining: HE.

As a result of an extensive revision work in the area, these authors proposed 4 sequential phases throughout the reproductive cycle of individuals able to reproduce: Developing, Spawning-capable, Regressing and Regenerating Phases, considering only sexually mature animals. Thus, according to these criteria, immature gonads would be disregarded, since they belong to individuals who are not able to reproduce yet, that is, young individuals, who do not show a current reproductive cycle (Brown-Peterson et al., 2011).

This proposal was initially developed for seawater Perciformes, although it is easily adaptable for the other Teleostei. However, especially among neotropical species, the researchers find some resistance in using it, either due to lack of knowledge of the proposal or even due to the difficulty in applying the data of its species to these reproductive phases. This fact is mainly due to the difficulty in classifying the gonadal stages of species from tropical regions, that present poorly defined seasons. For example, the gonadal stages of species that have multiple and asynchronous spawning (Winemiller, 1989), as in the case of Rhamdia quelen (Narahara et al., 1989) are confused due to the different characteristics presented by the gonads in the same period of the reproductive cycle. Thus, in making small adaptations to the proposal of Brown-Peterson and collaborators, this work can provide a great benefit to studies related to the reproductive biology of neotropical species, such as catfish. In this report, the correspondences of the names of the reproductive phases, according to Brown-Peterson and collaborators (2011) for the previously used names and their histological characterization were transcribed, adapted and illustrated so that these phases can be applied to Ostariophysi in general, using a representative of the order Siluriformes, the catfish $R$. quelen. A previous report described by this same research group was proposed for other neotropical Otophysi (Siluriformes and Characiformes) (Quagio-Grassiotto et al., 2013), showing that this adaptation is perfectly executable.

Different structural aspects of male and female gonads are used to classify gonadal stages throughout the reproductive cycle. However, these aspects are not the same when analyzing an ovary or testis. For example, the characterization of the reproductive phases in the Teleostei females does not use the same criteria applied to males that considers the changes of the male germinal epithelium (alternating from continuous to discontinuous epithelium) throughout their reproductive cycle. 

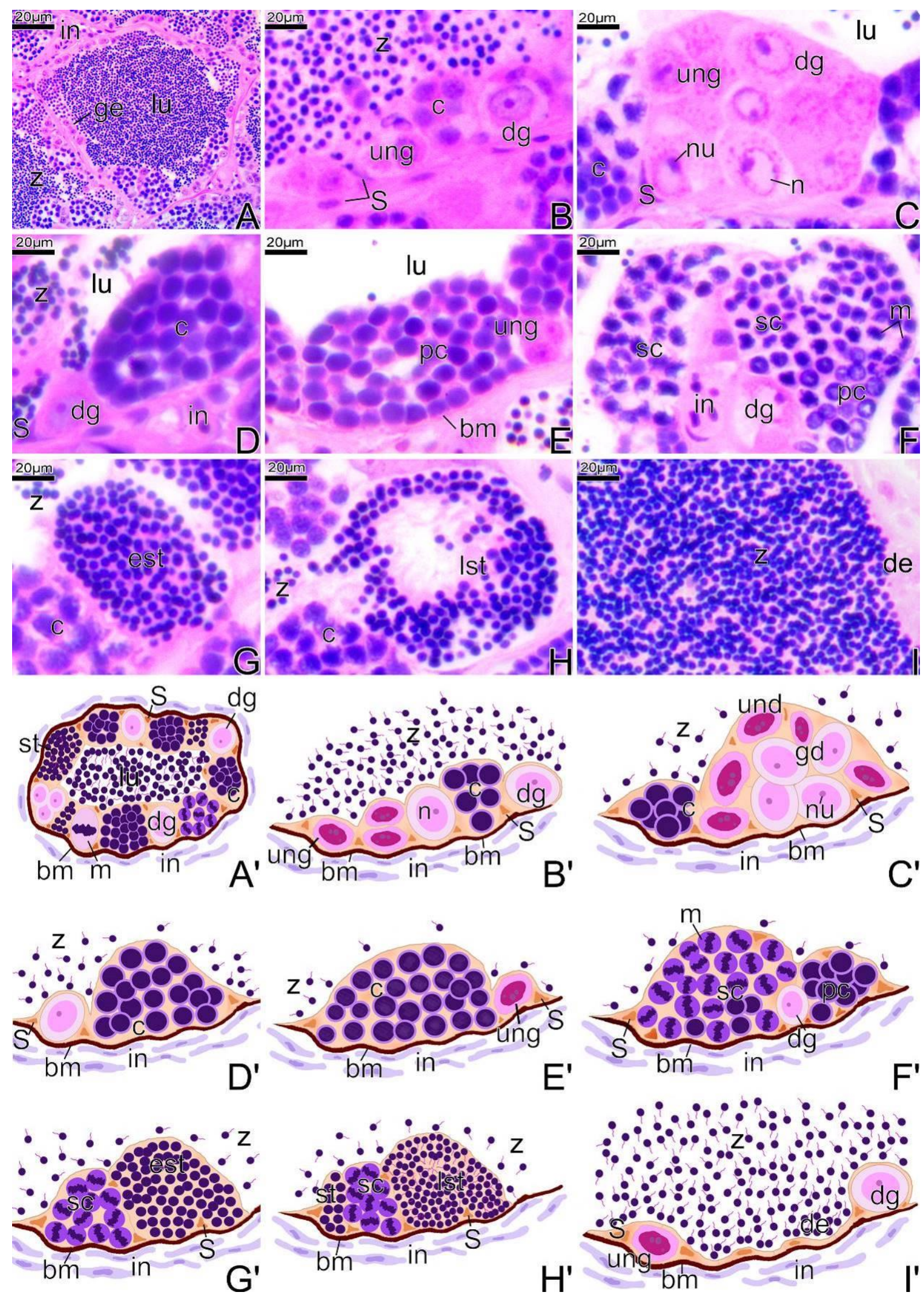

Figure 2. Spermatogenesis in Rhamdia quelen. A-I) Histological sections of the testis, 
showing the spermatocysts and male gametes cells in the germinal epithelium. A'-L') Schemes of the steps of the Spermatogenesis presented in A-L. A and A') Seminiferous tubule, showing the luminal compartment with spermatozoa. The germinal epithelium is continuous, formed by distinct spermatocysts. B and B') Isolated undifferentiated and differentiated spermatogonium. $\mathrm{C}$ and $\mathrm{C}^{\prime}$ ) Cysts of spermatogonia, formed by undifferentiated and differentiated spermatogonium. D and D') Differentiated spermatogonium surrounded by Serloti cell, forming a cyst. Cyst of primary spermatocytes. E and E') Cyst of spermatocytes, with a larger number of cells. Note the presence of undifferentiated spermatogonia in the germinal epithelium. The germinal epithelium rests on basement membrane. F and F') Cysts of primary and secondary spermatocytes. Secondary spermatocytes can be recognized by the nuclear division figures. $G$ and $\mathrm{G}^{\prime}$ ) Cyst of early spermatids. $\mathrm{H}$ and $\mathrm{H}^{\prime}$ ) Cyst of late spermatids. Note that flagella in formation of the spermatids can be observed. I and I') Luminal compartment of testicular tubule (seminiferous tubule) completely filled with spermatozoa. The germinal epithelium shows discontinuous. Germinal epithelium (ge), testicular lumen (lu), interstitium (in), spermatozoa (z), spermatocyte (c), undifferentiated spermatogonium (ung), differentiated spermatogonium (dg), Sertoli cell (S), nucleus (n), primary spermatocyte (pc), secondary spermatocyte (sc), basement membrane (bm), metaphase (m), spermatid (st), early spermatid (est), late spermatid (lst), discontinuous epithelium (de), nucleolus (nu). Staining: HE.

In females of $R$. quelen, as in the other Teleostei, the female germinal epithelium that borders the ovarian lamellae is always discontinuous throughout the reproductive cycle, since oogonium is dispersed in the lamellar epithelium, as well as the cell nests, resulting from its proliferation by mitosis and/or entrance into meiosis. These cellular aggregates form cell niches, i.e., regions formed by undifferentiated oogonia, cysts containing differentiated oogonia and cysts containing the early prophase oocytes. Thus, as a consequence of the existence of a permanently discontinuous female germinal epithelium, the reproductive phases in females are defined mainly based on the stages of oocyte development (Taylor et al., 1998; Brown-Peterson et al., 2011), although the proliferation and entry into meiosis of the germline cells begin gradually during Regressing Phase. In addition, these cell events are more intense in some specific phases of the reproductive cycle such as Regenerating and Development, and rarer during the Spawning Phase (Wildner et al., 2013). This means that the expansion of the cell nests occurs during the renewal of the ovarian tissue, after the end of a complete reproductive cycle and resumption of the process for a new spawning. The classifications and associated terminologies to describe female reproductive development in fishes has been adapted to $R$. quelen (Table 1).

In males, the histological characterization of the reproductive phases is based on the changes that occur in the epithelium of the seminiferous tubules throughout the reproductive cycle, considering the presence or absence of spermatocysts and the type of germ cells contained in these present spermatocysts. When the germinal epithelium of the testicular tubules is completely taken up by spermatocysts, it is said to be continuous. As the gonad develops and spermatogenesis advances and it is completed, the spermatocysts break open to release the spermatozoa in the testicular lumen. As a result of the non-replacement of the spermatocysts, 
the germinal epithelium gradually becomes formed only by Sertoli cells and, in this case, it is said to be discontinuous (Brown-Peterson et al., 2002; Grier and Uribe-Aránzabal, 2009; Brown- Peterson et al., 2011). Based on these changes in the germinal epithelium, the male reproductive phases were defined here for $R$. quelen, extending to the other neotropical Ostariophysi. The classifications and associated terminologies to describe male reproductive development in fishes has been adapted to R. quelen (Table 2).

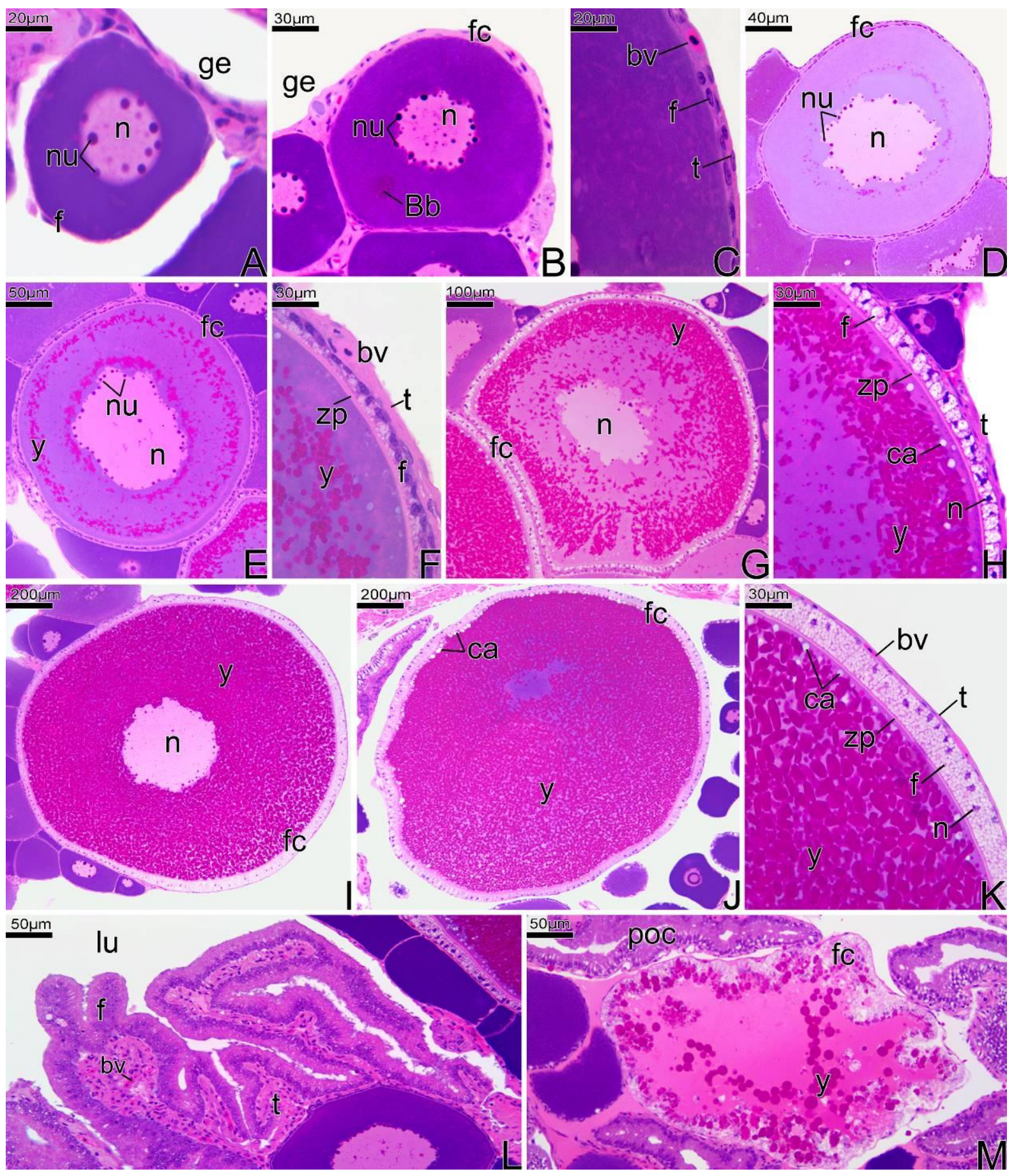

Figure 3. Oogenesis in Rhamdia quelen. A-D) Primary growth oocyte. C) Detail of B, showing the follicle envelopes of oocyte. At this stage, the follicle cells are squamous. Note the loss of cytoplasmic basophilia throughout primary growth. E) Secondary growth oocyte 
with initial vitellogenesis. F) Detail of E, showing the oocyte wraps. Note the presence of a small amount of secretion vesicles in the follicular cells. G) Oocyte in secondary growth with intermediate vitellogenesis. H) Detail of G, showing the follicle envelopes of oocyte. Note the presence of secretory vesicles in the follicle cells, which become cubic. I) Secondary growth oocyte (full-grown oocyte), with final vitellogenesis. The nucleus remains central. J) Mature oocyte, with eccentric nucleus. K) Detail of I, showing the follicle envelopes of oocyte. Both oocytes shown in I and $\mathrm{J}$ have cylindrical follicle cells, with a large amount of secretory vesicles. Its nucleus is basal. L) Postovulatory complex formed after release of the female gamete. The complex is formed by follicle cells, basement membrane and thecal cells. M) Atretic follicle, with irregular contour and partially liquefied yolk globules. Note the breakdown of follicle envelope. Germinal epithelium (ge), nucleus (n), nucleolus (nu), follicle cell (f), follicle complex (fc), Balbiani body (Bb), blood vessel (bv), theca (t), yolk globule (y), zona pellucida (zp), cortical alveolus (ca), ovarian lumen (lu), postovulatory complex (poc). Staining: HE.

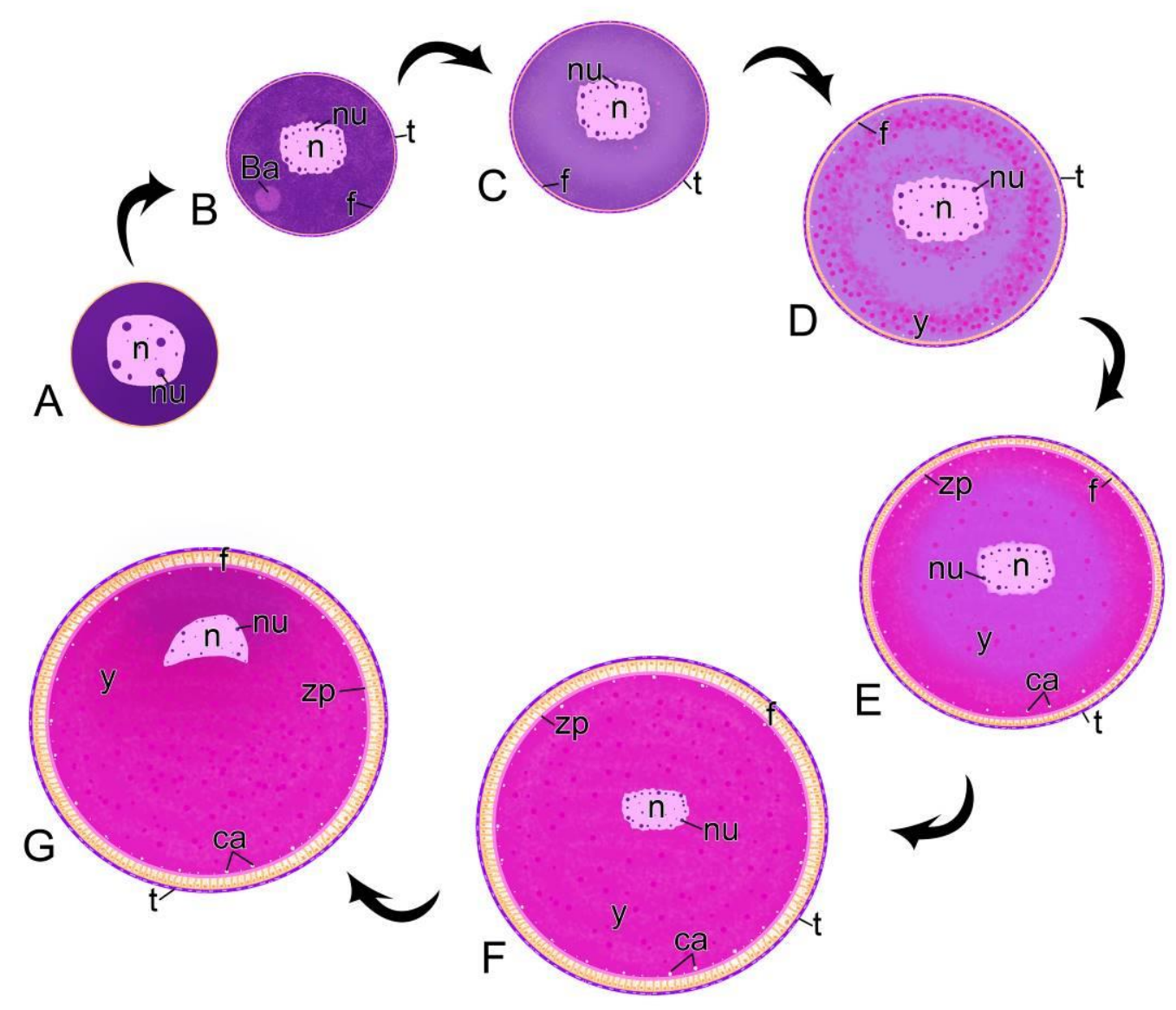

Figure 4. Scheme of the oogenesis in Rhamdia quelen. A-C) Primary growth oocytes. At this stage, the follicle cells are squamous. Note the loss of cytoplasmic basophilia throughout primary growth. D) Secondary growth oocytes with initial vitellogenesis. E) Secondary growth oocyte with intermediate vitellogenesis. F) Secondary growth oocyte (full-grown oocyte), with final vitellogenesis. The nucleus remains central. G) Mature oocyte, with eccentric nucleus. Nucleus (n), nucleolus (nu), follicle cell (f), Balbiani body (Bb), follicle 


\section{MInstitute ${ }^{\text {Mink }}$}

cell (f), theca (t), yolk globule (y), zona pellucida (zp), cortical alveolus (ca).
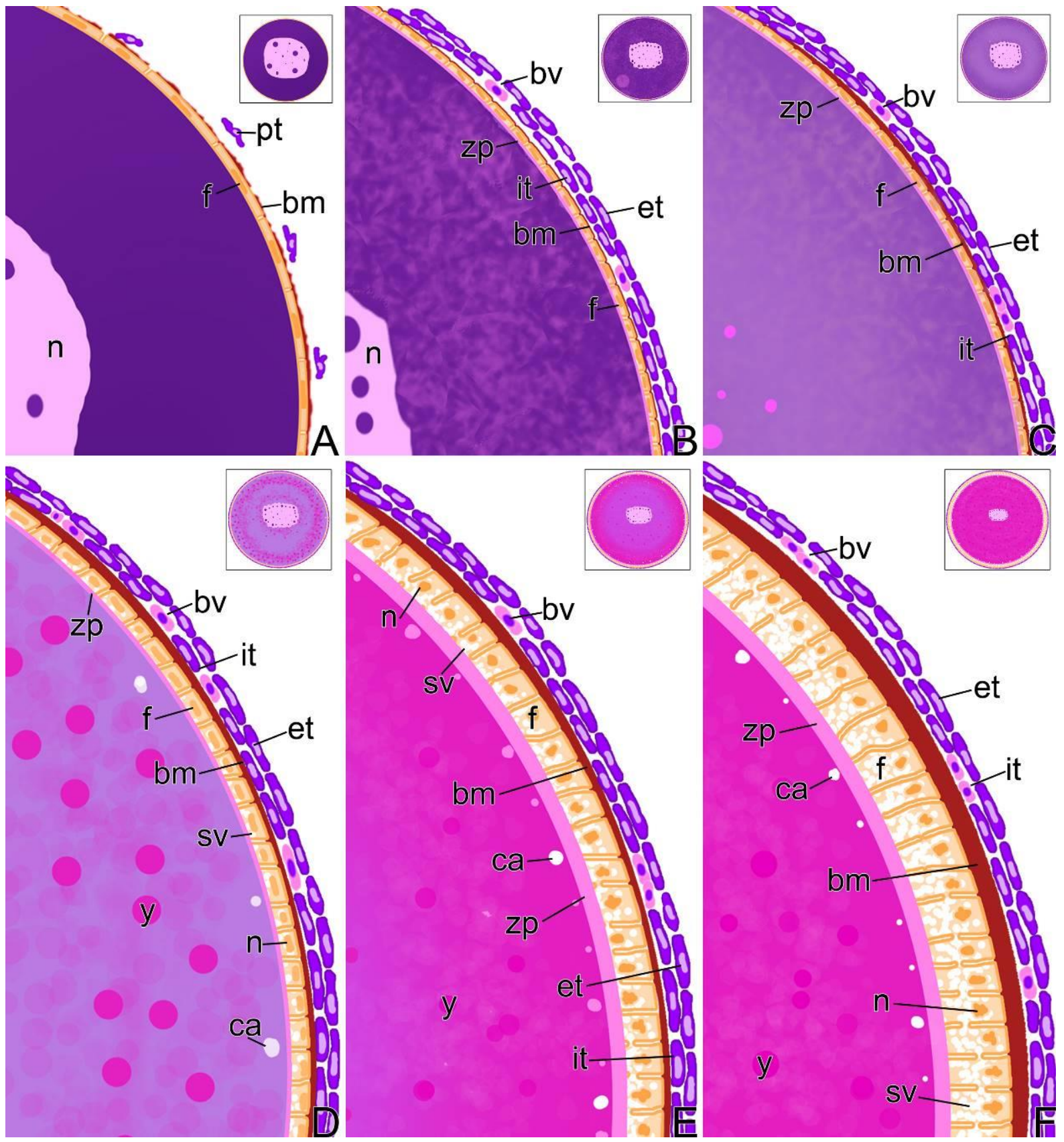

Figure 5. Scheme of follicle complex envelope of the oocyte during the oogenesis in Rhamdia quelen. A) Follicle complex of a primary growth oocyte (A-inset), formed by squamous follicle cells and a thin basement membrane. Pre-thecal cells will differentiate into theca when they contact the ovarian follicle. B and C) Follicle complex of a primary growth oocyte with cracked cytoplasm (B-inset, $\mathrm{C}$-inset), formed by squamous follicle cells and thin basement membrane. Follicle cells initiate the production of secretory vesicles. The theca is formed by two layers: internal theca (vascularized layer) and external theca. D) Follicle complex of a secondary growth oocyte with initial vitellogenesis (D-inset). The complex is 


\section{MInstitute ${ }^{\text {Mink }}$}

formed by follicle cells, basement membrane and theca cells. E) Follicle complex of a secondary growth oocyte with intermediate vitellogenesis (E-inset). The complex is formed by cubic follicle cells, basement membrane and theca cells. F) Follicle complex of a full-grown oocyte, with final vitellogenesis (F-inset). The complex is formed by cylindrical follicle cells, basement membrane and theca cells. Note the large amount of secretory vesicles in to follicle cells, that present basal nucleus. Nucleus (n), follicle cell (f), basement membrane (bm), pre-thecal cell (pt), blood vessel (bv), internal theca (it), external theca (et), zona pellucida (zp), yolk globule (y), cortical alveolus (ca), secretory vesicles (sv).

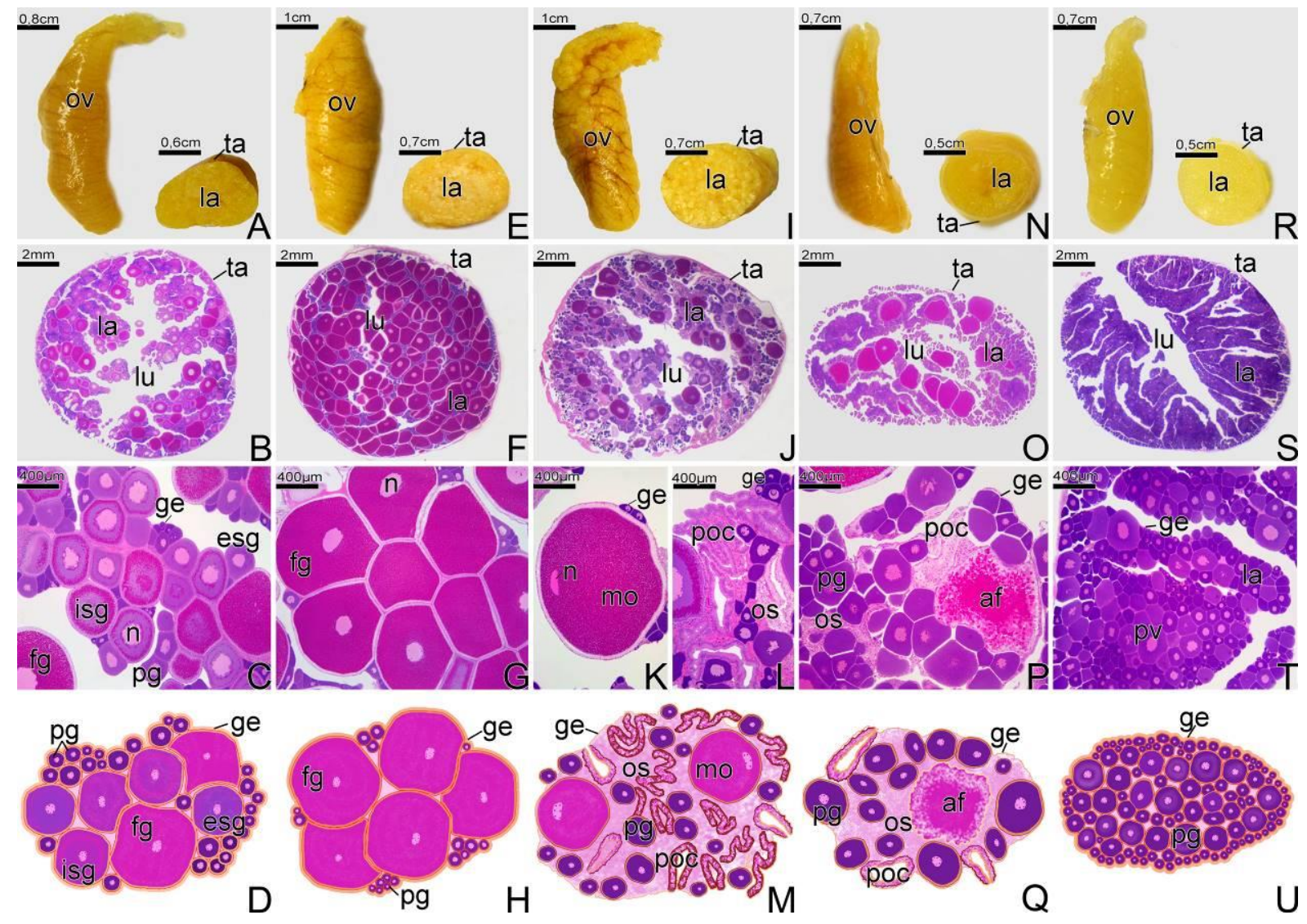

Figure 6. Characterization of the Female Reproductive Phases of Ramdia quelen. A-D) Developing Phase. A) Macroscopic view of the ovary in longitudinal and cross section. B) Cross section of the ovary. C) Detail of B, showing the ovigerous lamellae of the ovary, composed of oocytes in different growth stages (primary and secondary growth oocytes). D) Scheme of an ovary region in the Developing Phase, composed of primary and secondary growth oocytes. E-H) Spawning-capable Phase. E) Macroscopic view of the ovary in longitudinal and cross section. F) Cross section of the ovary. G) Detail of F, showing the ovigerous lamellae of the ovary, composed mainly of full-grown oocytes (in final vitellogenesis). H) Scheme of an ovary region in the Spawning-capable Phase, composed mainly of full-grown oocytes. Note the presence of primary growth oocytes (pre-vitellogenic oocytes). I-M) Actively Spawning Subphase. I) Macroscopic view of the ovary in longitudinal and cross section. J) Cross section of the ovary. K and L) Details of J, showing an oocyte with eccentric nucleus (mature oocyte) in $\mathrm{K}$ and a large amount of postovulatory 


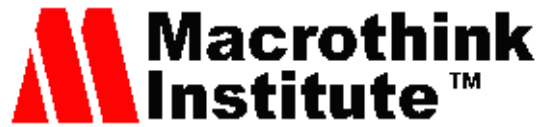

complexes in L. M) Scheme of an ovary region in the Actively Spawning Subphase, composed mainly of mature oocytes and a large number of postovulatory complexes. Note the ovarian stroma more developed in relation to the previous phase. N-Q) Regressing Phase. $\mathrm{N})$ Macroscopic view of the ovary in longitudinal and cross section. O) Cross section of the ovary. P) Detail of $\mathrm{O}$, showing the ovigerous lamellae of the ovary, composed of a large amount of pre-vitellogenic oocytes and some atretic follicles. Q) Scheme of an ovary region in the Regressing Phase, composed mainly of pre-vitellogenic oocytes, some atretic follicles and postovulatory complexes. Note the developed ovarian stroma. R-U) Ovary in the Regenerating Phase. R) Macroscopic view of the ovary in longitudinal and cross section. S) Cross section of the ovary. T) Detail of $S$, showing the ovigerous lamellae of the ovary, formed only by pre-vitellogenic oocytes. U) Scheme of an ovary region in the Regenerating Phase, composed of pre-vitellogenic oocytes. Ovary (ov), tunica albuginea (ta), ovigerous lamellae (la), ovarian lumen (lu), germinal epithelium (ge), secondary growth oocyte in early vitellogenesis (esg), secondary growth oocyte in intermediate vitellogenesis (isg), secondary growth oocyte in final vitellogenesis (full-grown oocyte) (fg), primary growth oocyte (pg), nucleus (n), mature oocyte (mo), postovulatory complex (poc), ovarian stroma (os), atretic follicle (af). Staining: HE.

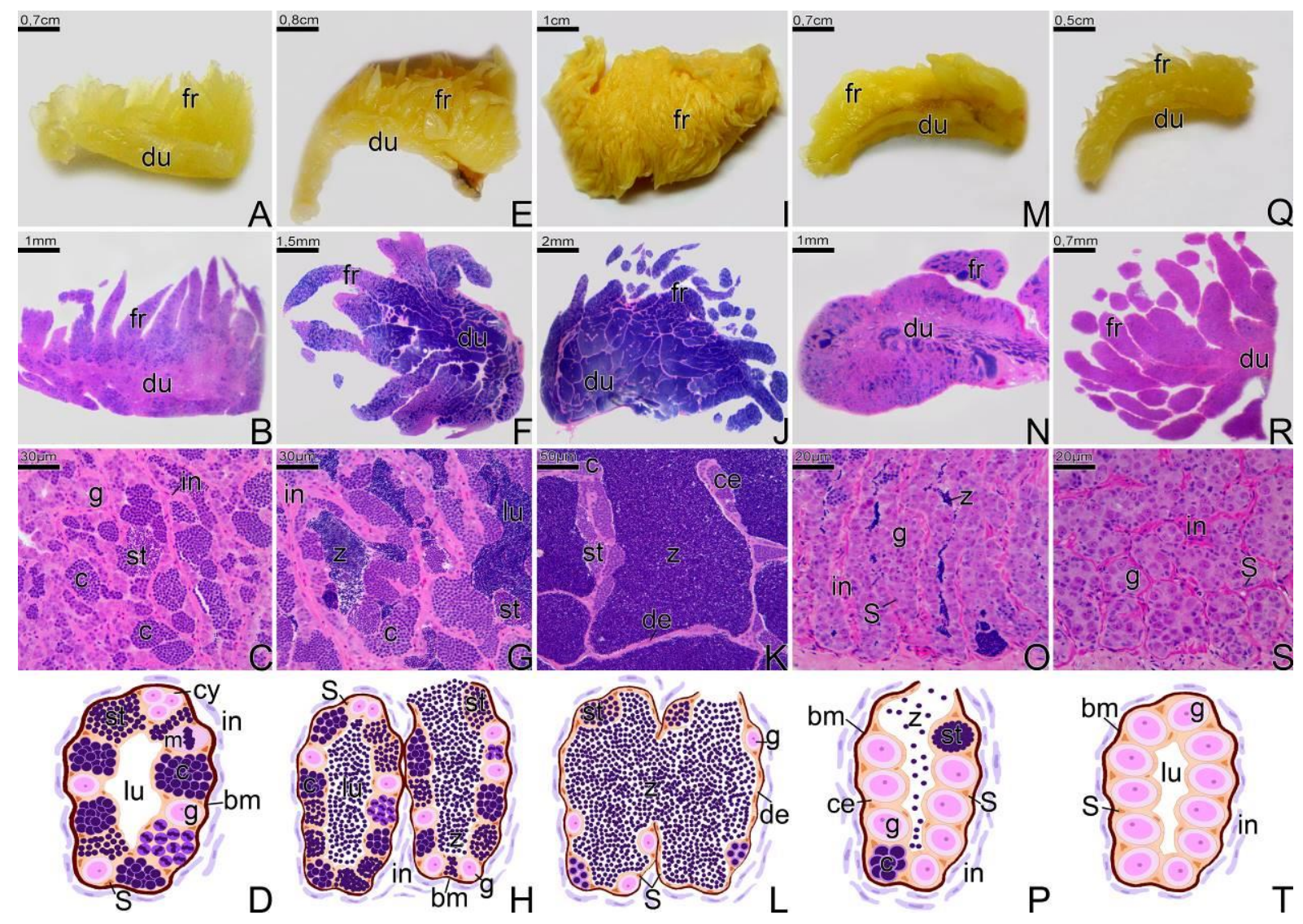

Figure 7. Characterization of the Male Reproductive Phases of Rhamdia quelen. A-D) Developing Phase. A) Macroscopic view of the testis. B) Longitudinal section of the testis. C) Detail of B, showing testicular tubules. The germinal epithelium of the tubules is continuous, consisting of cysts of spermatogonia, spermatocytes and spermatids. There are no sperm in 
the testicular lumen. D) Scheme of a testis region in the Developing Phase. Note the basement membrane separating the germinal and interstitial compartments. E-H) Extruding-capable Phase. E) Macroscopic view of the testis. F: Longitudinal section of the testis. G) Detail of F, showing testicular tubules. The germinal epithelium of the tubules is continuous, formed by cysts of spermatogonia, spermatocytes and spermatids. There are a lot of sperm in the testicular lumen. H) Scheme of a testis region in the Extruding-capable Phase. Note the basement membrane separating the germinal and interstitial compartments. I-L) Actively Extruding subphase. I) Macroscopic view of the testis. J) Longitudinal section of the testis. K) Detail of J, showing anastomosing testicular tubules. The germinal epithelium of the tubules is discontinuous, formed by few germline cysts. There are a lot of sperm in the testicular lumen. L) Scheme of a testis region in the Actively Extruding Subphase. Note the discontinuity of the germinal epithelium. M-P) Regressing phase. M) Macroscopic view of the testis. N) Longitudinal section of the testis. O) Detail of N, showing testicular tubules. The germinal epithelium of the tubules is continuous, formed mainly by cysts of spermatogonia. Residual sperm are noted in the testicular lumen. Note the interstitial compartment more developed in relation to the previous phase. P) Scheme of a testis region in the Regressing phase. Note the continuity of the germinal epithelium and the presence of residual sperm. Q-T) Testis in the Regenerating Phase. Q) Macroscopic view of the testis. R) Longitudinal section of the testis. S) Detail of R, showing testicular tubules. The germinal epithelium of the tubules is continuous, consisting only of cysts of spermatogonia. There are no sperm in the lumen, which is quite small. Note the developed interstitium. T) Scheme of a testis region in the Regenerating Phase. Note the continuity of the germinal epithelium, formed only by spermatogonia. Fringes (fr), spermatic duct (du), spermatogonia (g), interstitium (in), spermatocyte (c), spermatid (st), spermatozoa (z), continuous germinal epithelium (ce), Sertoli cell (S), testicular lumen (lu), discontinuous germinal epithelium (de), basement membrane (bm), metaphase (m). Staining: HE.

Although the reproductive period of both $R$. quelen and any other species may vary according to water conditions, temperature, food, management, etc., it is a consensus among the authors that this catfish shows two reproductive peaks per year (spring and summer) and multiple spawning (Narahara et al., 1989; Gomes et al., 2000). In other words, although the reproductive period may vary, depending on the conditions of the study, the gonadal morphological events and changes that classify the reproductive phases are very similar.

\section{Conclusions}

The proposal presented here for the use of a new classification of reproductive phases applied to neotropical fish hopes to facilitate the identification of gonadal structures in species that do not have reproductive cycles divided into defined reproductive periods. We hope that the schemes of the reproductive phases, as well as the drawing of the gametic cells can clarify understanding of the gonadal structure of the most diverse species of neotropical teleosts. 
Table $1 *$. Macroscopic and microscopic descriptions of the phases in the female reproductive cycle of Rhamdia quelen

\begin{tabular}{|c|c|c|}
\hline PHASE & $\begin{array}{l}\text { Previous } \\
\text { Terminology } \\
\text { (reproductive } \\
\text { period) }\end{array}$ & Ovaries - Macro and Microscopic Characteristics \\
\hline $\begin{array}{c}\text { IMMATURE } \\
\text { (never reproduced) }\end{array}$ & Maturing & $\begin{array}{l}\text { Small and clear ovaries. Only oogonia and primary growth } \\
\text { oocytes present; no atresia. Thin tunica albuginea. }\end{array}$ \\
\hline $\begin{array}{l}\text { DEVELOPING } \\
\text { (fish are not ready to } \\
\text { reproduce) } \\
\text { Figure 6A-D }\end{array}$ & $\begin{array}{l}\text { Early } \\
\text { Vitellogenesis } \\
\text { Final } \\
\text { Vitellogenesis }\end{array}$ & $\begin{array}{l}\text { Enlarging ovaries, blood vessels becoming more distinct. } \\
\text { Primary growth oocytes and early vitellogenic oocytes } \\
\text { present. No evidence of postovulatory complexes or } \\
\text { full-grown oocytes. Some atresia can be present. }\end{array}$ \\
\hline & $\begin{array}{l}\text { (late winter / } \\
\text { early spring) }\end{array}$ & \\
\hline SPAWNING & Mature & $\begin{array}{l}\text { Large ovaries; blood vessels prominent. Individual oocytes } \\
\text { visible macroscopically. Full-grown oocytes present. }\end{array}$ \\
\hline $\begin{array}{l}\text { CAPABLE } \\
\text { (fish are able to } \\
\text { reproduce in this } \\
\text { cycle) } \\
\text { Figure } 6 \mathbf{E - H}\end{array}$ & $\begin{array}{l}\text { Spawning } \\
\text { (spring / early } \\
\text { summer) }\end{array}$ & $\begin{array}{l}\text { Actively Spawning Subphase: final maturing oocytes; its } \\
\text { nucleus becomes eccentric. } \\
\text { Figure 6I-M }\end{array}$ \\
\hline $\begin{array}{l}\text { REGRESSING } \\
\text { (cessation of } \\
\text { spawning) } \\
\text { Figure 6N-Q }\end{array}$ & $\begin{array}{l}\text { Post-spawning } \\
\text { (late spring } \\
\text { to early autumn) }\end{array}$ & $\begin{array}{l}\text { Flaccid ovaries, blood vessels prominent. Atretic follicles } \\
\text { and postovulatory complexes present. Vitellogenic oocytes } \\
\text { can be present. }\end{array}$ \\
\hline $\begin{array}{l}\text { REGENERATING } \\
\text { (sexually mature, } \\
\text { reproductively } \\
\text { inactive) } \\
\text { Figure 6R-U }\end{array}$ & $\begin{array}{l}\text { (autumn / } \\
\text { winter) }\end{array}$ & $\begin{array}{c}\text { Small ovaries, thick tunica albuginea, blood vessels } \\
\text { reduced. Only oogonia and early prophase oocytes present. } \\
\text { Atretic follicles and postovulatory complexes may be } \\
\text { present. }\end{array}$ \\
\hline
\end{tabular}

The reproductive period reported here is in agreement with the data observed by Barcellos et al. (2001) in females. *Adapted from Brown-Peterson et al. (2011) and Quagio-Grassiotto et al. (2013). 
Table 2*. Macroscopic and microscopic descriptions of the phases in the male reproductive cycle of Rhamdia quelen

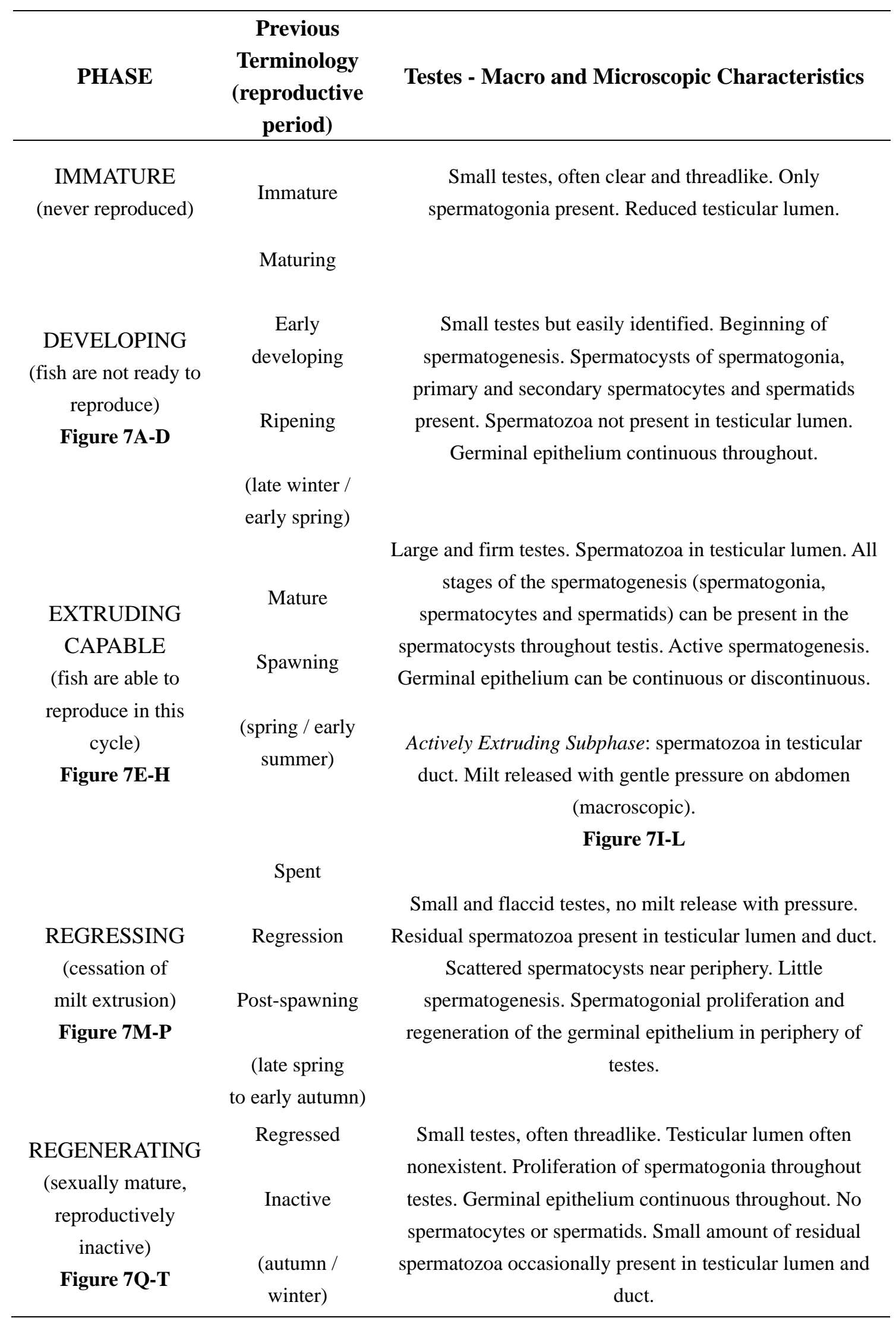


The reproductive period reported here is in agreement with the data observed by Barcellos et al. (2002) in males. *Adapted from Brown-Peterson et al. (2011) and Quagio-Grassiotto et al. (2013).

\section{References}

Albert, J. S., \& Reis, R. (Eds.). (2011). Historical biogeography of Neotropical freshwater fishes. University of California Press. https://doi.org/10.1525/california/9780520268685.001.0001

Angrizani, R. C., \& Malabarba, L. R. (2018). Morphology and molecular data reveal the presence of two new species under Rhamdia quelen (Quoy Gaimard, 1824) (Siluriformes: Heptapteridae) species complex. Zootaxa, 4388(1), 44-60. https://doi.org/10.11646/zootaxa.4388.1.3

Barcellos, L. J. G., Wassermann, G. F., Scott, A. P., Woehl, V. M., Quevedo, R. M., Ittzés, I., Krieger, M. H., \& Lulhier, F. (2002). Plasma steroid concentrations in relation to the reproductive cycle of cultured male Rhamdia quelen. Journal of Fish Biology, 61(3), 751-763. https://doi.org/10.1111/j.1095-8649.2002.tb00909.x

Barcellos, L. J., Wassermann, G. F., Scott, A. P., Woehl, V. M., Quevedo, R. M., Ittzés, I., ... Lulhier, F. (2001). Steroid profiles in cultured female jundia, the siluridae Rhamdia quelen (Quoy and Gaimard, Pisces Teleostei), during the first reproductive cycle. General and Comparative Endocrinology, 121(3), 325-332. https://doi.org/10.1006/gcen.2001.7603

Bockmann, F. A. (1998). Análise filogenética da família Heptapteridae (Teleostei, Ostariophysi, Siluriformes) e redefinição de seus gêneros. Unpublished. Doctoral dissertstion). Instituto de Biociências da Universidade de São Paulo, Departamento de Zoologia, São Paulo, Brazil.

Brown-Peterson, N. J., Grier, H. J., \& Overstreet, R. M. (2002). Annual changes in germinal epithelium determine male reproductive classes of the cobia. Journal of Fish Biology, 60(1), 178-202. https://doi.org/10.1111/j.1095-8649.2002.tb02397.x

Brown-Peterson, N. J., Wyanski, D. M., Saborido-Rey, F., Macewicz, B. J., \& Lowerre-Barbieri, S. K. (2011). A standardized terminology for describing reproductive development in fishes. Marine and Coastal Fisheries, 3(1), 52-70. https://doi.org/10.1080/19425120.2011.555724

França, G. F., Grier, H. J., \& Quagio-Grassiotto, I. (2010). A new vision of the origin and the oocyte development in the Ostariophysi applied to Gymnotus sylvius (Teleostei: $\begin{array}{llll}\text { Gymnotiformes). } \quad \text { Neotropical } & \text { Ichthyology, } & \text { 8(4), }\end{array}$ https://doi.org/10.1590/S1679-62252010000400008

Gomes, L. D. C., Golombieski, J. I., Gomes, A. R. C., \& Baldisserotto, B. (2000). Biologia do jundiá Rhamdia quelen (TELEOSTEI, PIMELODIDAE). Ciência Rural, 30(1), 179-185. https://doi.org/10.1590/S0103-84782000000100029

Grier, H. J. (2002). The germinal epithelium: its dual role in establishing male reproductive 
classes and understanding the basis for indeterminate egg production in female fishes. In Proceedings of the fifty-third annual Gulf and Caribbean Fisheries Institute (Creswell, R.L. ed.). November 2000. (pp. 537-552). Fort Pierce: Mississippi/Alabama Sea Grant Consortium. http://aquaticcommons.org/13529/1/gcfi_53-47.pdf

Grier, H. J., \& Uribe-Aranzábal, M. C. (2009). The Testis and Spermatogenesis in Teleosts. In Jamieson, B.J.M. (Ed): Reproductive Biology and Phylogeny of Fishes (Agnathans and Bony Fishes) Phylogeny Reproductive System Viviparity Spermatozoa. 802p.

Grier, H. J., Uribe-Aranzábal, M. C., \& Patiño, R. (2009). The ovary, folliculogenesis and oogenesis in teleosts. In Jamieson, B.J.M. (Ed): Reproductive Biology and Phylogeny of Fishes (Agnathans and Bony Fishes) Phylogeny Reproductive System Viviparity Spermatozoa. 802p.

Jamieson, B. G. M. (Ed.). (2009). Reproductive biology and phylogeny of fish (Agnatha and Osteichthyes) Phylogeny-Reproductive System-Viviparity-Spermatozoa. Enfield: Science Publishers. https://doi.org/10.1201/9781482280609

Jin, Y., Liu, S., Yuan, Z., Yang, Y., Tan, S., \& Liu, Z. (2016). Catfish genomic studies: progress and perspectives. In Genomics in Aquaculture (pp. 73-104). Academic Press. https://doi.org/10.1016/B978-0-12-801418-9.00004-4

Lowerre-Barbieri, S. K., Brown-Peterson, N. J., Murua, H., Tomkiewicz, J., Wyanski, D. M., \& Saborido-Rey, F. (2011). Emerging issues and methodological advances in fisheries reproductive biology. Marine and Coastal Fisheries, 3(1), 32-51. https://doi.org/10.1080/19425120.2011.555725

Malabarba, L. R., \& Malabarba, M. C. (2020). Phylogeny and classification of Neotropical fish. In Biology and Physiology of Freshwater Neotropical Fish (pp. 1-19). Academic Press. https://doi.org/10.1016/B978-0-12-815872-2.00001-4

Mann, R. H. K. (1984). Geographical variation in the life-history tactics of some species of freshwater fish. In G.W. Potts and R.J Wootton (Eds): Fish reproduction: strategies and tactics, (pp. 171-186). Wootton. Academic Press, London.

Mazzoni, T. S., \& Grassiotto, I. Q. (2017). Ovary Differentiation and Activity in Teleostei Fish. In Theriogenology, 7, 129-156. https://doi.org/10.5772/intechopen.69022

Mazzoni, T. S., Grier, H. J., \& Quagio-Grassiotto, I. (2010). Germline cysts and the formation of the germinal epithelium during the female gonadal morphogenesis in Cyprinus carpio (Teleostei: Ostariophysi: Cypriniformes). The Anatomical Record, 293(9), 1581-1606. https://doi.org/10.1002/ar.21205

Mazzoni, T. S., Grier, H. J., \& Quagio-Grassiotto, I. (2014). Male gonadal differentiation and the paedomorphic evolution of the testis in Teleostei. The Anatomical Record, 297(6), 1137-1162. https://doi.org/10.1002/ar.22915

Nakamura, S., Kobayashi, K., Nishimura, T., \& Tanaka, M. (2011). Ovarian germline stem cells in the teleost fish, medaka (Oryzias latipes). International journal of biological sciences, 
7(4), 403. https://doi.org/10.7150/ijbs.7.403

Nakamura, S., Kobayashi, K., Nishimura, T., Higashijima, S. I., \& Tanaka, M. (2010). Identification of germline stem cells in the ovary of the teleost medaka. Science, 328(5985), 1561-1563. https://doi.org/10.1126/science.1185473

Narahara, M. Y., Godinho, H. M., \& Romagosa, E. (1989). Tipo de desova e fecundidade do bagre, Rhamdia hilarii (Valenciennes, 1840) (Siluriformes, Pimelodidae). Boletim do Instituto de Pesca, 16(1), 37-45.

Nelson, J. S., Grande, T. C., \& Wilson, M. V. (2016). Fishes of the World. 5th ed. John Wiley \& Sons. https://doi.org/10.1002/9781119174844

Pepling, M. E., De Cuevas, M., \& Spradling, A. C. (1999). Germline cysts: a conserved phase of germ cell development? Trends in cell biology, 9(7), 257-262. https://doi.org/10.1016/S0962-8924(99)01594-9

Quagio-Grassiotto, I., Grier, H. J., Mazzoni, T. S., Nóbrega, R. H., \& Amorim, J. P. (2011). Activity of the ovarian germinal epithelium on the follicle formation and the oocyte development in the freshwater catfish Pimelodus maculatus (Teleostei: Ostariophysi: Siluriformes). Journal of Morphology, 272, 1290-1306. https://doi.org/10.1002/jmor.10981

Quagio-Grassiotto, I., Malabarba, L. R., Azevedo, M. A., Burns, J. R., Baicere-Silva, C. M., \& Quevedo, R. (2012). Unique derived features in spermiogenesis and sperm morphology supporting a close relationship between the species of Hollandichthys and Rachoviscus (Characiformes: Characidae). Copeia, 2012(4), 609-625. https://doi.org/10.1643/CG-11-171

Quagio-Grassiotto, I., Wildner, D. D., \& Ishiba, R. (2013). Gametogênese em peixes: aspectos relevantes para o manejo reprodutivo. Revista brasileira de reprodução animal, 181-191. http://www.cbra.org.br/pages/publicacoes/rbra/v37n2/pag181-191\%20(RB448).pdf

Schulz, R. W., França, L. R., Lareyre, J. J., LeGac, F., Chiarini-Garcia, H., Nobrega, R. H., \& Miura, T. (2010). Spermatogenesis in fish. General and comparative endocrinology, 165(3), 390-411. https://doi.org/10.1016/j.ygcen.2009.02.013

Taylor, R. G., Grier, H. J., \& Whittington, J. A. (1998). Spawning rhythms of common snook in Florida. Journal of Fish Biology, 53(3), 502-520. https://doi.org/10.1111/j.1095-8649.1998.tb00998.x

Vari, R. P., \& Malabarba, L. R. (1998). Neotropical Ichthyology: an overview in Phylogeny and Classification of Neotropical Fishes pp. 1-11 En: L. Malabarba, RE Reis, RP Vari, CAS de Lucena, ZMS de Lucena (eds.) Phylogeny and Classification of Neotropical Fishes, Museu de Ciencias e Tecnologia Porto Alegre. https://doi.org/10.1016/B978-0-12-815872-2.00001-4

Vazzoler, A. E. A. M. (1996). Biologia da reprodução de peixes Teleósteos. Teoria e Prática. Maringá: EDUEM.

Wildner, D. D., Grier, H., \& Quagio-Grassiotto, I. (2013). Female germ cell renewal during the annual reproductive cycle in Ostariophysians fish. Theriogenology, 79(4), 709-724. 


\section{Macrothink}

https://doi.org/10.1016/j.theriogenology.2012.11.028

Winemiller, K. O. (1989). Patterns of variation in life history among South American fishes in seasonal environments. Oecologia, 81(2), 225-241. https://doi.org/10.1007/BF00379810

\section{Copyrights}

Copyright for this article is retained by the author(s), with first publication rights granted to the journal.

This is an open-access article distributed under the terms and conditions of the Creative Commons Attribution license (http://creativecommons.org/licenses/by/4.0/) 